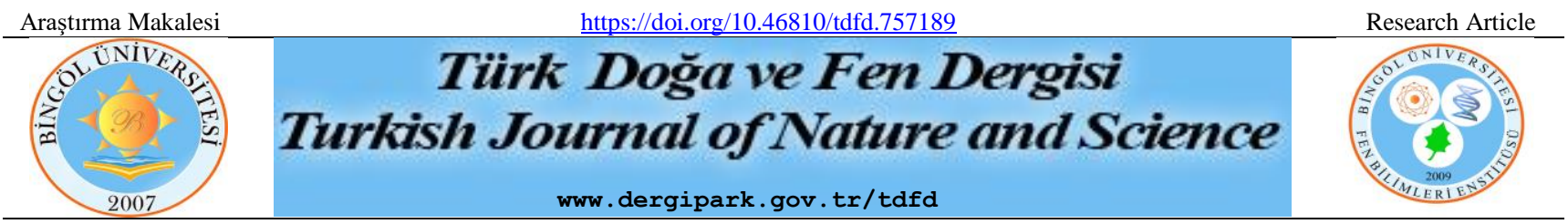

\title{
Bingöl Ovası'nda Yetiştiriciliği Yapılan Yoncaların (Medicago sativa L.) Verim ve Kalitelerinin Belirlenmesi
}

\author{
Erdal ÇAÇAN ${ }^{*}$, İhsan ARSLAN ${ }^{2}$ \\ ${ }^{1}$ Bingöl Üniversitesi, Gıda Tarım ve Hayvancılık Meslek Yüksekokulu, Bitkisel ve Hayvansal Üretim Bölümü, Bingöl, \\ Türkiye \\ ${ }^{2}$ Bingöl Üniversitesi, Fen Bilimleri Enstitüsü, Tarla Bitkileri Anabilim Dalı, Bingöl, Türkiye \\ Erdal ÇAÇAN ORCID No: 0000-0002-9469-2495 \\ İhsan ARSLAN ORCID No: 0000-0003-4790-0711 \\ *Sorumlu yazar: ecacan@bingol.edu.tr
}

(Alınış: 24.06.2020, Kabul: 24.02.2021, Online Yayınlanma: 25.06.2021)

\section{Anahtar \\ Kelimeler \\ Yonca, \\ Bingöl ovas1, \\ Ot verimi, \\ Ot kalitesi}

Öz: Bu çalışma, Bingöl ovası köylerinde yetiştiriciliği yapılan yoncaların, verim ve kalitesinin belirlenmesi amacıyla 2018 yılında yürütülmüştür. Çalışma kapsamında, Bingöl ovasında yer alan 39 adet yonca tarlası ziyaret edilmiştir. Ziyaret edilen tarlalarda bitki boyu ölçülmüş, tesadüfi üç tekerrürlü olarak alınan örnekler üzerinden yeşil ot ve kuru ot verimleri hesaplanmıştır. Kurutulan ve öğütülen ot örneklerine ait kalite parametreleri, NIRS cihazı ile analiz edilmiştir. İncelenen tüm özellikler arasında tespit edilen farkların istatistiksel olarak anlamlı olduğu $(\mathrm{P}<0,01)$ görülmüştür. Çalışmada; bitki boyu 59,3-109,3 cm, yeşil ot verimi 1016-4683 kg da ${ }^{-1}$, kuru ot verimi 230-1050 $\mathrm{kg} \mathrm{da}^{-1}$, ham protein oran1 \%16,2-23,5, ham protein verimi 44,3-193,2 $\mathrm{kg} \mathrm{da}^{-1}$, ADF (asit deterjanda çözünmeyen lif) oranı \%25,7-35,7, NDF (nötral deterjanda çözünmeyen lif) oranı \%33,9-46,4, SKM (sindirilebilir kuru madde) oranı \%61,1-68,9, KMT (kuru madde tüketimi) oranı \%2,59-3,57 ve NYD (nispi yem değeri) ise 123-191 arasında değişim göstermiştir. En yüksek verim (yeşil ve kuru ot verimi) Garip köyüne ait birinci tarladan, en yüksek kalite ise (düşük ADF, NDF ile yüksek SKM, KMT ve NYD) Kumgeçit köyüne ait ikinci tarladan elde edilmiştir. Bölgede yonca yetiştiriciliği yapan çiftçilerin sertifikalı tohumluk kullanmaları tavsiye edilmektedir. Ancak çeşitli nedenlerden dolayı yerel genotiplere ait tohumlukların tercih edilmesi durumunda, Garip köyü ve Kumgeçit köylerinde kullanılan tohumlukların tercih edilmesi verim ve kalite açısından avantajlı olacağı anlaşılmıştır.

\section{Determination of Yield and Quality of Alfalfa Cultivated In Bingöl Plain}

Keywords Alfalfa, Bingöl plain, Forage quality, Forage yield

\begin{abstract}
This study was carried out in 2018 to determine the yield and forage quality of the alfalfa that was grown in villages in the Bingöl plain. Within the scope of the study, 39 alfalfa fields in Bingöl plain were visited. In the fields visited, the plant height was measured, and the forage and dry matter yields were calculated from the samples taken as random three replications. Quality parameters of dried and ground forage samples were analyzed with NIRS device. The differences between the examined features were found to be statistically significant $(\mathrm{P}<0.01)$. In the study; plant height 59.3-109.3 cm, forage yield 1016-4683 kg da ${ }^{-1}$, dry matter yield $230-1050 \mathrm{~kg} \mathrm{da}^{-1}$, crude protein ratio 16.2-23.5\%, crude protein yield 44.3-193.2 $\mathrm{kg} \mathrm{da}^{-1}$, ADF (insoluble fiber in acid detergent) ratio 25.7-35.7\%, NDF (insoluble fiber in neutral detergent) ratio 33.9-46.4\%, DDM (digestible dry matter) ratio 61.1-68.9\%, DMI (dry matter intake) 2.59-3.57\% and RFV (relative feed value) varied between 123-191. The highest yield (forage and dry matter yield) was obtained from the first field of Garip village and the highest quality (low ADF, NDF and high DDM, DMI and RFV) was obtained from the second field of Kumgeçit village. Farmers growing alfalfa in the region are recommended to use certified seeds. However, if the seeds of local genotypes are preferred for various reasons, it is understood that the seeds used in Garip village and Kumgeçit villages will be preferred in terms of yield and quality.
\end{abstract}




\section{GİRIŞ}

Yonca, yem bitkilerinin en değerlisi ve kültürü yapılan en eski yem bitkisidir. Adını Medya Otu anlamına gelen Herba Medica'dan almaktadır. Yonca M.Ö. 1350 yıllarında Hitit Uygarlığı döneminde Anadolu'da yetiştiriciliği yapıldığı daha sonra M.Ö. 490 yılında Medler ve Persler tarafindan anavatanından (TransKafkaslar, İran ve Anadolu) Yunanistan'a, oradan da Roma'ya götürüldüğü bilinmektedir. Dünyada 18 . yüzyılda bilinçli bir şekilde tarımı yapılmaya başlanmış ve bir üretim dalı haline gelmiştir (1).

Yonca cinsi içerisinde yaklașı olarak 50 tür bulunmaktadır. $\mathrm{Bu} 50$ türün sadece on tanesi tarımsal açıdan önem taşımaktadır. Bunlar; Medicago sativa, $M$. falcata, M. varia, M. lupilina, M. hispida, M. maculata, M. tuberculata, M. scutellata, M. elegans ve $M$. orbicularis'tir. Yonca türleri içerisinde en çok önem taşıyanı ve en çok yetiştiriciliği yapılanı yaygın yonca (Medicago sativa)'dır. Yaygın yonca çok yıllık olup, hemen hemen dünyanın her yerinde yetişebilen tipleri bulunmaktadir (2).

Dünyada en çok yetiştirilen yem bitkisi yonca olup, diğer yem bitkilerine göre daha yüksek yem değerine sahiptir. Yonca, birim alanda yüksek verim verir ve gerek yeşil otu gerekse kuru otu tüm hayvanlar için hem lezzetli hem de besleyicidir. Ancak otu, yeşil olarak fazla yedirildiğinde ruminant hayvanlarda şişkinlik yapmaktadır (3).

Yoncadan çiftlik hayvanlarının beslenmesinin yanı sıra, baz1 uygulamalar sonucunda elde edilen yonca küplerinden petlerin beslenmesinde (tavşan, hamster, vb) ve yonca unundan ise kanatliların beslenmesinde yararlanılmaktadir. Son zamanlarda yonca yapraklarından plastik hammaddesi, saplarından ise etanol üretilmektedir (2).
Yonca uzun ömürlü bir bitki olduğundan, iyi adapte olduğu yerlerde uzun yillar yaşarsa da normal olarak 7 10 yıl ekonomik ürün verir. Bir mevsimde birçok defa biçilebilir. Bir mevsimde ve sulu şartlarda Doğu Anadolu Bölgesinde 2-3, İç Anadolu Bölgesinde 4-5, Ege ve Marmara Bölgelerinde 7-8 ve Güneydoğu Anadolu Bölgesinde ise 8-10 defa biçim alınabilmektedir (4).

Yoncanın; Doğu Anadolu Bölgesinde yeșil ot veriminin $3106-3795 \mathrm{~kg} / \mathrm{da}$, kuru ot veriminin $1102-1315 \mathrm{~kg} / \mathrm{da}$ $(5,6)$, İç Anadolu Bölgesinde kuru ot veriminin 1499$1761 \mathrm{~kg} / \mathrm{da}(7)$, Ege Bölgesinde yeşil ot veriminin 9515 $11885 \mathrm{~kg} / \mathrm{da}$, kuru ot veriminin 2031-2710 kg/da $(8,9)$, Akdeniz Bölgesinde yeşil ot veriminin $4443 \mathrm{~kg} / \mathrm{da}$ ve kuru ot verimi $1139 \mathrm{~kg} / \mathrm{da}$ (10) arasında olduğu bildirilmiştir.

Bingöl ilinde Doğu Anadolu Bölgesinin diğer illerinde olduğu gibi hayvancılığın temel girdisi olan kaba yem ihtiyacının karşılanması için yonca yetiştiriciliği yapılmaktadır. Yoncanın Bingöl ovasında çiftçi şartlarında elde edilen verim ve kalitenin belirlenmesi amacıyla bu çalışma yürütülmüştür.

\section{MATERYAL VE METOT}

\subsection{Materyal}

Araştırmanın materyalini; Bingöl Ovası'nda yonca tarımının yoğun olarak yapıldığı Ekinyolu, Sarıçiçek, Yeniköy, Dik, Çeltiksuyu, Büyüktekören, Çayağzı, Kumgeçit, Garip, Ormanardı ve Güveçli köyleri ile Bingöl il merkezine bağlı Kültür mahallesine ait tarlalardan alınan yonca örnekleri oluşturmaktadır. Örneklemenin yapıldığı lokasyon haritası Şekil 1'de verilmiştir.

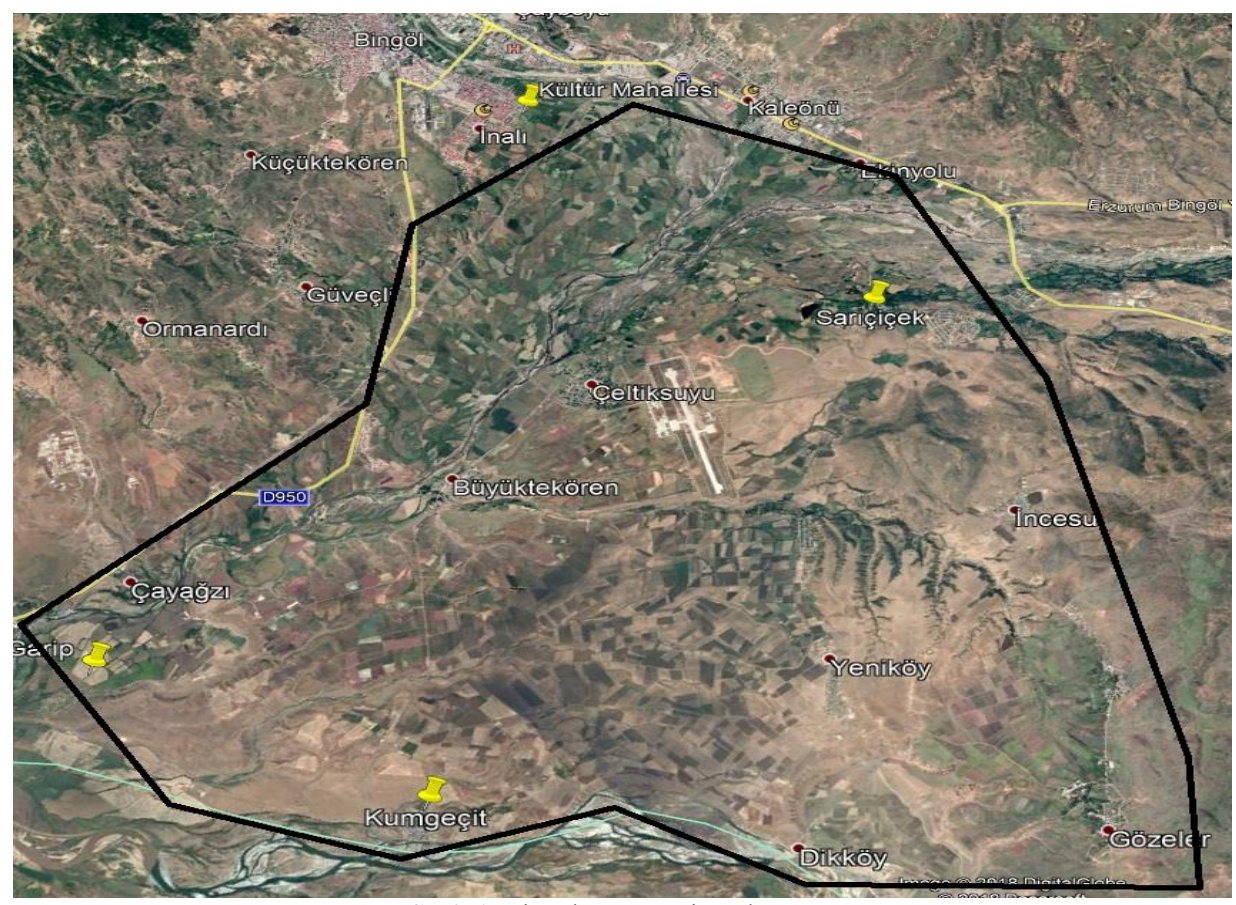

Şekil 1. Bingöl ovasına ait uydu görüntüsü 
Bingöl ovasında ziyaret edilen tarlalara ait enlem, boylam ve rakım bilgileri Tablo 1'de verilmiştir. Buna göre 12 farklı lokasyonda bulunan 39 adet yonca tarlası ziyaret edilerek yerel yoncalar ile ilgili gözlemler yapılmış ve numuneler alınmıştır.

Tablo 1. Bingöl Ovası'nda bulunan yonca tarlalarına ait konum bilgileri

\begin{tabular}{|c|c|c|c|c|c|c|c|}
\hline & Mahalle / Köy & Enlem-Boylam & Rakım & No & Mahalle / Köy & Enlem-Boylam & Rakım \\
\hline 1 & Kültür Mahallesi Tarla 1 & $38.89610-40.54067$ & 1055 & 20 & Çayağzı Tarla 1 & $38.79164-40.54766$ & 1000 \\
\hline 2 & Kültür Mahallesi Tarla 2 & $38.89755-40.54519$ & 1031 & 21 & Ormanard 1 Tarla 1 & $38.81860-40.55639$ & 1013 \\
\hline 3 & Kültür Mahallesi Tarla 3 & $38.88614-40.53582$ & 1055 & 22 & Çeltiksuyu Tarla 1 & $38.87028-40.60964$ & 1093 \\
\hline 4 & Kültür Mahallesi Tarla 4 & $38.88311-40.54418$ & 1036 & 23 & Çeltiksuyu Tarla 2 & $38.86288-40.61286$ & 1087 \\
\hline 5 & Kültür Mahallesi Tarla 5 & $38.88188-40.55136$ & 1035 & 24 & Çeltiksuyu Tarla 3 & $38.85879-40.58092$ & 1052 \\
\hline 6 & Kültür Mahallesi Tarla 6 & $38.86585-40.54032$ & 1026 & 25 & Çeltiksuyu Tarla 4 & $38.85565-40.56434$ & 1023 \\
\hline 7 & Kültür Mahallesi Tarla 7 & $38.86330-40.53316$ & 1048 & 26 & Çeltiksuyu Tarla 5 & $38.84095-40.57355$ & 1022 \\
\hline 8 & Kumgeçit Tarla 1 & $38.80339-40.62371$ & 1045 & 27 & Çeltiksuyu Tarla 6 & $38.84683-40.57334$ & 1030 \\
\hline 9 & Kumgeçit Tarla 2 & $38.80470-40.62567$ & 1051 & 28 & Sarıçiçek Tarla 1 & $38.88459-40.60665$ & 1085 \\
\hline 10 & Ekinyolu Tarla 1 & $38.90205-40.56402$ & 1042 & 29 & Sarıçiçek Tarla 2 & $38.88582-40.60733$ & 1086 \\
\hline 11 & Güveçli Tarla 1 & $38.84628-40.54765$ & 1030 & 30 & Sarıçiçek Tarla 3 & $38.88031-40.60824$ & 1088 \\
\hline 12 & Güveçli Tarla 2 & $38.84428-40.55406$ & 1025 & 31 & Sarıçiçek Tarla 4 & $38.89874-40.60876$ & 1052 \\
\hline 13 & Büyüktekören Tarla 1 & $38.82454-40.58627$ & 1068 & 32 & Sarıçiçek Tarla 5 & $38.89880-40.60816$ & 1051 \\
\hline 14 & Büyüktekören Tarla 2 & $38.82604-40.58529$ & 1065 & 33 & Dikköy Tarla 1 & $38.84271-40.63778$ & 1086 \\
\hline 15 & Garip Tarla 1 & $38.79567-40.56308$ & 1003 & 34 & Dikköy Tarla 2 & $38.84234-40.63742$ & 1084 \\
\hline 16 & Garip Tarla 2 & $38.79460-40.56303$ & 1000 & 35 & Dikköy Tarla 3 & $38.83768-40.63170$ & 1084 \\
\hline 17 & Garip Tarla 3 & $38.78687-40.56329$ & 994 & 36 & Yeniköy Tarla 1 & $38.85300-40.62359$ & 1079 \\
\hline 18 & Garip Tarla 4 & $38.79277-40.56924$ & 1003 & 37 & Yeniköy Tarla 2 & $38.85392-40.62023$ & 1082 \\
\hline \multirow[t]{2}{*}{19} & Garip Tarla 5 & $38.78836-40.56675$ & 994 & 38 & Yeniköy Tarla 3 & $38.85192-40.61748$ & 1080 \\
\hline & & & & 39 & Yeniköy Tarla 4 & $38.85354-40.62053$ & 1082 \\
\hline
\end{tabular}

Bingöl iline ait bazı iklim verileri incelendiğinde; uzun yıllar (1975-2009) aylık ortalama sıcaklığın $11,5{ }^{\circ} \mathrm{C}$, toplam yağış miktarının $962,9 \mathrm{~mm}$ ve ortalama nispi nem değerinin ise $\% 56,7$ olduğu rapor edilmiştir. Araştırmanın yürütüldüğü 2018 yılının, uzun yıllar ortalamasından daha sıcak $\left(14,6{ }^{\circ} \mathrm{C}\right)$, daha az yağışlı $(905,0 \mathrm{~mm})$ ve nispi nem değerinin de daha düşük $(\% 54,1)$ olduğu görülmüştür (Tablo 2).
Bingöl ovası topraklarının pH'sının 6,37 ile 8,18, kireç içeriklerinin $\% 0,04$ ile $\% 9,90$, EC değerinin $102,6 \mu \mathrm{S} / \mathrm{cm}$ ile $624,5 \mu \mathrm{S} / \mathrm{cm}$, organik madde oranlarının $\% 0,35$ ile $\% 2,78, \mathrm{~B}$ oranlarının $\% 0,33$ ile $\% 0,48, \mathrm{~N}$ oranlarının $\% 0,17$ ile $\% 0,22, \mathrm{P}$ oranlarının $\% 4,13$ ile $\% 7,86, \mathrm{Fe}$ oranlarının $\% 12,78$ ile $\% 18,24, \mathrm{Zn}$ oranlarının $\% 0,32$ ile $\% 0,41, \mathrm{Cu}$ oranlarının \%0,33 ile $\% 1,37$ ve $\mathrm{Mn}$ oranlarının \%3,96 ile \%4,63 arasında değişim gösterdiği bildirilmiştir (12).

Tablo 2. Bingöl iline ait bazı iklim verileri (11)

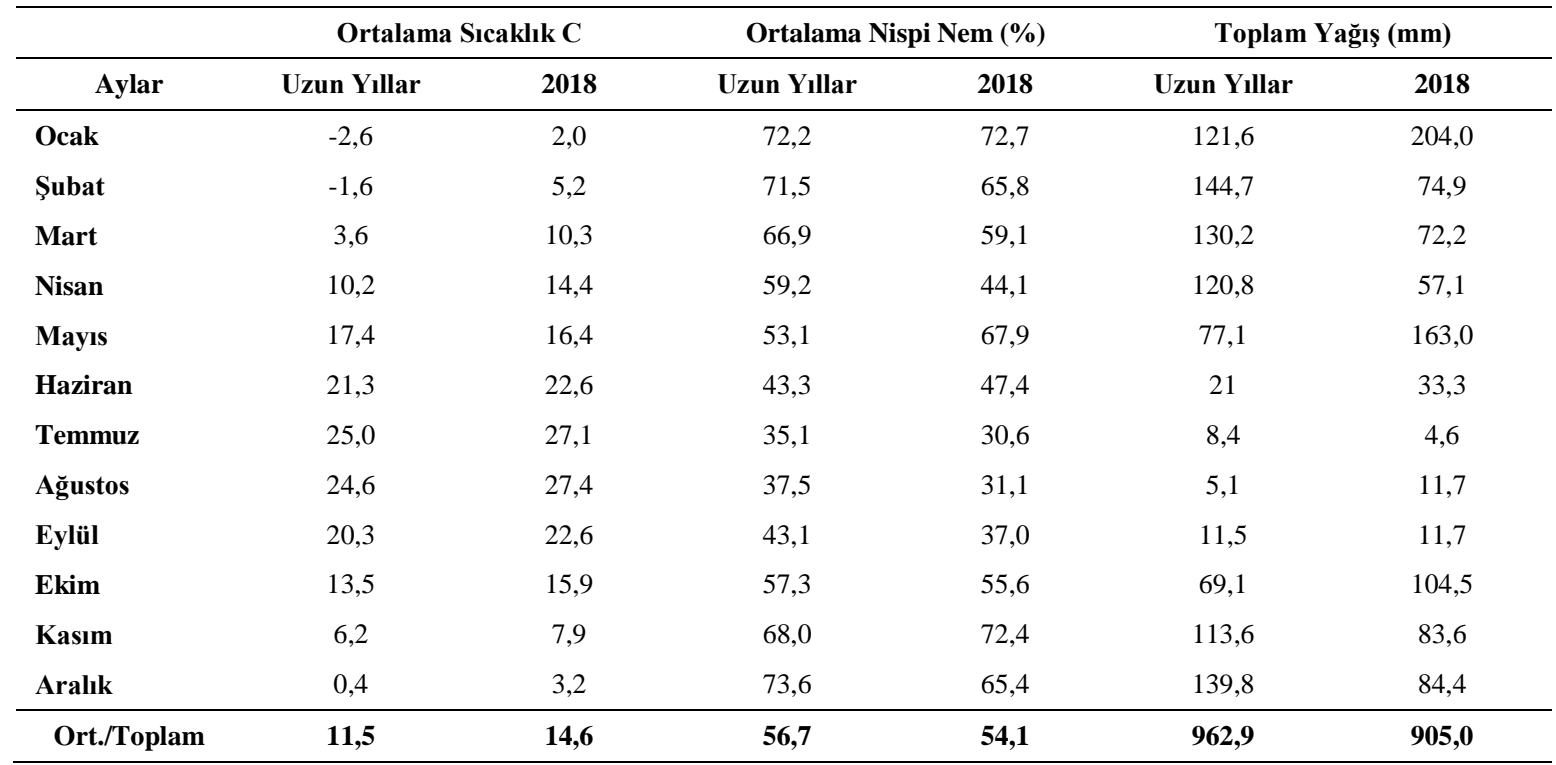




\subsection{Metot}

Araştırmada bitki örneklemesi ve ölçümler; yonca yetiştiriciliğinin yapıldığı toplam 39 üretici tarlasından, yoncaların ikinci biçiminde, çiçeklenme başlangıcında yapılmıştır. Her tarladan rastgele seçilen 30 adet bitkinin toprak seviyesi ile en yüksek noktasına kadar olan kısmı ölçülerek bitki boyu değerleri belirlenmiştir. Her tarlaya rastgele atılan üç adet $33 \mathrm{~cm}$ x $33 \mathrm{~cm}$ ebatlarındaki metal çerçeve içerisinde kalan bitkiler, toprak yüzeyinden biçilerek çerçevelerin yeşil ot ağırlıkları belirlenmiş, çerçeve alanı dikkate alınarak her bir örnekleme noktasına ait yoncaların dekara yeşil ot verimleri tespit edilmiştir. Biçilen bu otlardan 0,5 kg'llk örnekler alınarak kurutma dolabında 48 saat $70{ }^{\circ} \mathrm{C}$ 'de kurutulduktan sonra tartım yapılmış ve kuru ot ağırlığı elde edilmiştir. Elde edilen kuru ot değerleri daha sonra dekara verime çevrilmiştir (13).

Kuru ot ağırlığı tespit edilen otlar öğütülerek analize hazır hale getirilmiştir. Kuru ot örneklerinin ham protein (HP), asit deterjanda çözünmeyen lif (ADF) ve nötral deterjanda çözünmeyen lif (NDF) oranı analizleri, Dicle Üniversitesi Bilim ve Teknoloji Uygulama ve Araştırma Merkezi Laboratuvarında NIRS (Near Infrared Spektroscopy-Foss Model 6500) cihazı yardımıyla yapılmıştır.

Kuru otta tespit edilen HP oranlarının dekara kuru ot verimleri ile çarpılarak dekara HP verimleri hesaplanmıştır $(14,15)$. Yonca örneklerinde sindirilebilir kuru madde (SKM), kuru madde tüketimi (KMT) ve nispi yem değeri (NYD) aşağıdaki eşitlikler yardımıyla belirlenmiştir $(16,17)$.

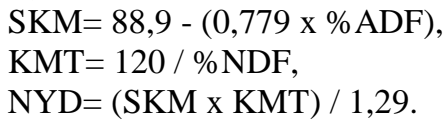

Elde edilen verilere, JMP istatistik paket programı yardımıyla varyans analizi uygulanmış, grupların farklılıkları Tukey testi ile karşılaştırılmıştır (18).

\section{BULGULAR}

\subsection{Bitki Boyu, Yeşil Ot ve Kuru Ot Verimleri}

Bingöl Ovası'nda yetiştiriciliği yapılan yonca genotiplerinin bitki boyları, yeşil ot verimleri, kuru ot verimleri, ham protein oranları ve ham protein verimlerine ait değerler ve ortalamalar Tablo 3'te, ADF, NDF, SKM ve KMT oranları ile nispi yem değerleri ile ilgili değerler ve ortalamalar ise Tablo 4 'te verilmiştir. İncelenen bu özellikler arasındaki farkların istatistiki açıdan \%1 düzeyinde önemli olduğu görülmüştür.

Bingöl Ovası'nda yetiştiriciliği yapılan yonca genotiplerine ait bitki boylarının 59,3-109,3 cm arasında değiştiği ve ortalamasının da $82,1 \mathrm{~cm}$ olduğu tespit edilmiştir. En yüksek bitki boyunun Kültür Mahallesi'nde yer alan yedinci tarladan, en düşük bitki boyunun ise Çeltiksuyu Köyü'ne ait birinci tarladan ve Kumgeçit Köyü'ne ait ikinci tarladan elde edildiği görülmüştür (Tablo 3).
Daha önce yapılan çalışmalar, farklı çeşitlerle ve farklı yetişme koşullarında yürütüldüğünden bitki boyu ile ilgili farklı değerler elde edilmesi beklenen bir durumdur. Örneğin Bingöl koşullarında yürütülen bu çalışmada yoncanın bitki boyu ortalaması $82,1 \mathrm{~cm}$ olarak elde edilirken, İzmir koşullarında 68,8-71,1 cm (8), Erzurum koşullarında $67,7 \mathrm{~cm}$ (19) ve Yozgat koşullarında 70,4-78,3 cm (7) olarak elde edilmiştir.

Yonca genotiplerine ait yeşil ot verimleri 1016-4683 kg $\mathrm{da}^{-1}$, kuru ot verimleri ise $230-1050 \mathrm{~kg} \mathrm{da}^{-1}$ arasinda değişmiştir. Yeşil ot verimi ortalaması $2817 \mathrm{~kg} \mathrm{da}^{-1}$, kuru ot verimi ortalamas1 ise $684 \mathrm{~kg} \mathrm{da}^{-1}$ olarak elde edilmiştir. En yüksek yeşil ot veriminin Garip Köyü'nde yer alan birinci tarladan, en düşük yeşil ot veriminin ise Kumgeçit Köyü'ne ait birinci tarladan elde edildiği görülmüştür. En yüksek kuru ot veriminin Garip Köyü'nde yer alan birinci ve beşinci tarlalardan, en düşük kuru ot veriminin ise Kumgeçit Köyü'nün ikinci tarlasından elde edildiği belirlenmiştir (Tablo 3).

Daha önce yapılan çalışmalara bakıldığında; Şanlıurfa koşullarında yoncanın yeşil ot verimi $2796 \mathrm{~kg} \mathrm{da}^{-1}$, kuru ot verimi $817 \mathrm{~kg} \mathrm{da}^{-1}(20)$, Bingöl koşullarında yeşil ot verimi $2735-3591 \mathrm{~kg} \mathrm{da}^{-1}$, kuru ot verimi 924,1-1227,3 $\mathrm{kg} \mathrm{da}^{-1}$ (6), Van koşullarında yeşil ot verimi 2922-4358 $\mathrm{kg} \mathrm{da}^{-1}$, kuru ot verimi ise 787-1620 $\mathrm{kg} \mathrm{da}^{-1}$ (5) olarak elde edilmiştir. Daha önce yapılan bu çalışmalarda elde edilen yeşil ot ve kuru ot verimlerinin yüksekliği biçim sayısının fazlalığından kaynaklanmaktadır.

Mevcut çalışmada sadece yoncaların ikinci biçimine denk gelen bir adet biçim sonuçları değerlendirilmeye alınmıştır. Bingöl koşullarında yılda ortalama dört biçim alınmaktadır (6). Ancak genel olarak ilk biçim ve son biçimden elde edilen yeşil ot verimi ve kuru ot verimleri daha düşük olmaktadır. $\mathrm{Bu}$ durum göz önünde bulundurulduğunda, esasında bu çalışmadan elde edilen yeşil ot ver kuru ot verimlerinin, ortalama üç katı ile çarpılması durumunda gereceğe yakın verim değerleri elde edilecektir.

\subsection{Ham Protein Oranları ve Verimleri}

Yonca genotiplerine ait ham protein oranları \%16,223,5 , ham protein verimleri ise 44,3-193,2 $\mathrm{kg} \mathrm{da}^{-1}$ arasında değişmiştir. Ham protein oranı ortalaması $\% 19,0$, ham protein verimi ortalamas1 ise $129,5 \mathrm{~kg} \mathrm{da}^{-1}$ olarak elde edilmiştir. En yüksek ham protein oranı Çeltiksuyu Köyü'nde yer alan üçüncü tarladan, en düşük ham protein oranı Garip Köyü'nde yer alan üçüncü tarladan, en yüksek ham protein verimi Sarıçiçek Köyü'nde yer alan birinci tarladan, en düşük ham protein verimi ise Kumgeçit Köyü'nde yer alan birinci tarladan elde edilmiştir (Tablo 3).

Ham protein oranları, İzmir koşullarında \%17,9-20,3 (21), Doğu ve Güneydoğu Anadolu'dan toplanan bazı yonca klonlarında \%17,1-23,2 (22) ve Tokat koşullarında \%17,1-18,8 (23) olarak elde edilen değerler ile benzerlik göstermektedir. Bitkiler, çevre koşullarının etkisi ve genetik yapılarındaki farklılıklardan dolayı 
farklı ekolojilerde farklı verimler vermektedirler. Ham protein verimi de ham protein oranı ve kuru ot verimi ile elde edilen bir parametre olduğundan, bu değerlerin farklılık gösterdiği yerlerde ham protein verimi de farklılıklar göstermektedir.

Tablo 3. Yonca genotiplerine ait bitki boyları, yeşil ot verimleri, kuru ot verimleri, ham protein oranları, ham protein verimleri ve oluşan gruplar**

\begin{tabular}{|c|c|c|c|c|c|c|}
\hline & Köy Adı & $\begin{array}{l}\text { Bitki Boyu } \\
(\mathbf{c m})\end{array}$ & $\begin{array}{c}\text { Yeşil Ot } \\
\text { Verimi }\left(\mathrm{kg} \mathrm{da}^{-1}\right)\end{array}$ & $\begin{array}{c}\text { Kuru Ot } \\
\text { Verimi }\left(\mathrm{kg} \mathrm{da}^{-1}\right)\end{array}$ & $\begin{array}{c}\text { Ham Protein } \\
\text { Oranı (\%) }\end{array}$ & $\begin{array}{c}\text { Ham Protein } \\
\text { Verimi }\left(\mathrm{kg} \mathrm{da}^{-1}\right)\end{array}$ \\
\hline 1 & Büyüktekören-1 & $74,4 \mathrm{k}-\mathrm{q}$ & $2610 b-j$ & $723 \mathrm{a}-\mathrm{f}$ & $18,3 \mathrm{c}-\mathrm{i}$ & $134,1 \mathrm{a}-\mathrm{g}$ \\
\hline 2 & Büyüktekören-2 & $81,2 \mathrm{~g}-\mathrm{k}$ & $2247 \mathrm{c}-\mathrm{j}$ & $626 a-h$ & 17,9 e-i & $112,2 \mathrm{a}-\mathrm{h}$ \\
\hline 3 & Cayağz1 & $67,3 n-q$ & $1263 \mathrm{hij}$ & $346 \mathrm{fgh}$ & $17,3 \mathrm{f}-\mathrm{i}$ & $59,8 \mathrm{fgh}$ \\
\hline 4 & Celtiksuyu-1 & $59,3 \mathrm{q}$ & $1842 \mathrm{e}-\mathrm{j}$ & $995 \mathrm{c}-\mathrm{h}$ & 20,2 b-f & $100,2 \mathrm{c}-\mathrm{h}$ \\
\hline 5 & Celtiksuyu-2 & 79,9 h-1 & 3580 a-d & $894 a b c$ & $18,4 \mathrm{c}-\mathrm{i}$ & $165,1 \mathrm{a}-\mathrm{d}$ \\
\hline 6 & Celtiksuyu-3 & 76,9 j-m & $3080 \mathrm{a}-\mathrm{g}$ & $543 \mathrm{c}-\mathrm{h}$ & $23,5 \mathrm{a}$ & 127,6 a-h \\
\hline 7 & Celtiksuyu-4 & 85,0 e-j & 3597 a-d & 839 a-d & $19,4 \mathrm{c}-\mathrm{h}$ & 162,8 a-e \\
\hline 8 & Celtiksuyu-5 & $69,8 \mathrm{~m}-\mathrm{p}$ & $1603 \mathrm{~g}-\mathrm{j}$ & 404 e-h & $20,1 \mathrm{~b}-\mathrm{g}$ & $81,1 \mathrm{~d}-\mathrm{h}$ \\
\hline 9 & Celtiksuyu-6 & $74,0 \mathrm{k}-\mathrm{o}$ & $3917 \mathrm{abc}$ & 832 a-e & 20,2 b-f & $167,7 \mathrm{a}-\mathrm{d}$ \\
\hline 10 & Dik-1 & $90,2 \mathrm{c}-\mathrm{g}$ & $3187 \mathrm{a}-\mathrm{g}$ & 823 a-e & $18,2 \mathrm{~d}-\mathrm{i}$ & 150,6 a-e \\
\hline 11 & Dik-2 & $65,2 \mathrm{opq}$ & $1647 \mathrm{~g}-\mathrm{j}$ & 432 d-h & $18,1 \mathrm{~d}-\mathrm{i}$ & 77,6 e-h \\
\hline 12 & Dik-3 & $85,1 \mathrm{e}-\mathrm{j}$ & $2880 \mathrm{~b}-\mathrm{i}$ & 777 a-f & $19,8 \mathrm{c}-\mathrm{h}$ & 153,9 a-e \\
\hline 13 & Ekinyolu & 78,0 i-m & $2187 \mathrm{c}-\mathrm{j}$ & $543 \mathrm{c}-\mathrm{h}$ & $19,2 \mathrm{c}-\mathrm{i}$ & $105,0 \mathrm{~b}-\mathrm{h}$ \\
\hline 14 & Garip-1 & 93,2 cde & $4683 \mathrm{a}$ & $1050 \mathrm{a}$ & 17,9 e-i & $187,1 \mathrm{ab}$ \\
\hline 15 & Garip-2 & $91,2 \mathrm{c}-\mathrm{f}$ & 2977 a-h & 743 a-f & $19,8 \mathrm{c}-\mathrm{h}$ & 146,4 a-f \\
\hline 16 & Garip-3 & $87,8 \mathrm{~d}-\mathrm{h}$ & $3637 \mathrm{a}-\mathrm{d}$ & $871 a b c$ & 16,2 i & $140,9 \mathrm{a}-\mathrm{f}$ \\
\hline 17 & Garip-4 & 93,0 cde & $3820 \mathrm{abc}$ & 819 a-e & $18,6 \mathrm{c}-\mathrm{i}$ & 153,6 a-e \\
\hline 18 & Garip-5 & $105,0 \mathrm{ab}$ & $4310 \mathrm{ab}$ & $1050 \mathrm{a}$ & 17,7 e-i & $186,2 \mathrm{ab}$ \\
\hline 19 & Güveçli-1 & $62,3 \mathrm{pq}$ & $1907 \mathrm{~d}-\mathrm{j}$ & $477 \mathrm{c}-\mathrm{h}$ & $20,1 \mathrm{~b}-\mathrm{f}$ & $96,0 \mathrm{c}-\mathrm{h}$ \\
\hline 20 & Güveçli-2 & $97,2 \mathrm{bc}$ & 2923 b-h & 730 a-f & 20,6 a-e & 150,0 a-e \\
\hline 21 & Kumgeçit-1 & 66,3 n-q & $1016 \mathrm{j}$ & $261 \mathrm{gh}$ & 16,9 ghi & $44,3 \mathrm{~h}$ \\
\hline 22 & Kumgeçit-2 & 59,9 q & $1187 \mathrm{ij}$ & $230 \mathrm{~h}$ & $23,1 \mathrm{ab}$ & $52,9 \mathrm{gh}$ \\
\hline 23 & Kültür-1 & $66,1 \mathrm{n}-\mathrm{q}$ & $2340 \mathrm{c}-\mathrm{j}$ & $650 a-h$ & $16,8 \mathrm{hi}$ & 108,0 a-h \\
\hline 24 & Kültür-2 & $89,6 \mathrm{c}-\mathrm{g}$ & $2893 \mathrm{~b}-\mathrm{i}$ & 750 a-f & $18,3 \mathrm{c}-\mathrm{i}$ & 137,2 a-f \\
\hline 25 & Kültür-3 & 85,4 e-j & $1773 \mathrm{f}-\mathrm{j}$ & $530 \mathrm{c}-\mathrm{h}$ & $18,1 \mathrm{~d}-\mathrm{i}$ & $95,7 \mathrm{c}-\mathrm{h}$ \\
\hline 26 & Kültür-4 & $81,2 \mathrm{~g}-\mathrm{k}$ & $2613 b-j$ & $613 b-h$ & $21,1 \mathrm{a}-\mathrm{d}$ & 129,3 a-h \\
\hline 27 & Kültür-5 & 86,2 e-i & $2580 \mathrm{~b}-\mathrm{j}$ & $661 \mathrm{a}-\mathrm{h}$ & 19,0 c-i & $125,4 \mathrm{a}-\mathrm{h}$ \\
\hline 28 & Kültür-6 & $95,8 \mathrm{~cd}$ & 3537 a-e & 839 a-d & $21,4 \mathrm{abc}$ & $182,2 \mathrm{abc}$ \\
\hline 29 & Kültür-7 & $109,3 \mathrm{a}$ & 2977 a-h & 783 a-e & 17,4 e-i & 136,4 a-f \\
\hline 30 & Ormanard 1 & $74,8 \mathrm{k}-\mathrm{n}$ & 3463 a-f & $673 \mathrm{a}-\mathrm{g}$ & $18,4 \mathrm{c}-\mathrm{i}$ & 123,8 a-h \\
\hline 31 & Sarıçiçek-1 & $90,8 \mathrm{c}-\mathrm{f}$ & $4097 \mathrm{ab}$ & $1016 \mathrm{ab}$ & $18,9 \mathrm{c}-\mathrm{i}$ & $193,2 \mathrm{a}$ \\
\hline 32 & Sarıçiçek-2 & $85,8 \mathrm{e}-\mathrm{j}$ & $2723 b-j$ & 780 a-e & $19,0 \mathrm{c}-\mathrm{i}$ & 147,8 a-e \\
\hline 33 & Sarıçiçek-3 & $97,4 \mathrm{bc}$ & $3113 \mathrm{a}-\mathrm{g}$ & $752 \mathrm{a}-\mathrm{f}$ & $18,7 \mathrm{c}-\mathrm{i}$ & $141,2 \mathrm{a}-\mathrm{f}$ \\
\hline 34 & Sarıçiçek-4 & $82,8 \mathrm{f}-\mathrm{k}$ & $2617 b-j$ & $583 \mathrm{c}-\mathrm{h}$ & $18,3 \mathrm{c}-\mathrm{i}$ & 107,0 a-h \\
\hline 35 & Sarıçiçek-5 & $86,2 \mathrm{e}-\mathrm{i}$ & $3050 \mathrm{~b}-\mathrm{g}$ & 719 a-f & $17,7 \mathrm{e}-\mathrm{i}$ & 127,7 a-h \\
\hline 36 & Yeniköy-1 & $90,3 \mathrm{c}-\mathrm{g}$ & $3283 \mathrm{a}-\mathrm{g}$ & 815 a-e & $19,0 \mathrm{c}-\mathrm{i}$ & 154,8 a-e \\
\hline 37 & Yeniköy-2 & $81,4 \mathrm{~g}-\mathrm{k}$ & $2830 \mathrm{~b}-\mathrm{i}$ & $666 \mathrm{a}-\mathrm{g}$ & $19,9 \mathrm{c}-\mathrm{h}$ & 131,3 a-h \\
\hline 38 & Yeniköy-3 & $85,2 \mathrm{e}-\mathrm{j}$ & $3167 \mathrm{a}-\mathrm{g}$ & $747 \mathrm{a}-\mathrm{f}$ & $18,4 \mathrm{c}-\mathrm{i}$ & 137,9 a-f \\
\hline 39 & Yeniköy-4 & $71,41-\mathrm{p}$ & $2663 \mathrm{~b}-\mathrm{j}$ & $600 \mathrm{~b}-\mathrm{h}$ & $19,6 \mathrm{c}-\mathrm{h}$ & 117,6 a-h \\
\hline \multicolumn{2}{|r|}{ Ortalama } & 82,1 & 2817 & 684 & 19,0 & 129,5 \\
\hline **: & $\leq 0,01, \quad$ CV $(\%)$ & 3,39 & 18,70 & 19,17 & 4,03 & 20,22 \\
\hline
\end{tabular}

\subsection{ADF, NDF, SKM ve KMT Oranları ile Nispi Yem Değerleri}

Yonca genotiplerine ait asit deterjanda çözünmeyen lif oranları \%25,7-35,7 arasında değiştiği ve ortalamasının \%29,6, nötral deterjanda çözünmeyen lif oranlarının \%33,9-46,4 arasında değiştiği ve ortalamasının da \%39,2 olduğu olduğu tespit edilmiştir. En yüksek ADF ve NDF oranları Ormanardı Köyü’nde yer alan tarladan, en düşük
ADF ve NDF oranları da Kumgeçit Köyü'nde yer alan ikinci tarladan elde edildiği görülmüştür (Tablo 4).

Yonca genotiplerinin ortalama olarak SKM oranları $\% 65,9$, KMT oranları \%3,09 ve nispi yem değerleri ise 158 olarak elde edilmiştir. En düşük SKM ve KMT oranları Ormanardı köyüne ait tarladan, en yüksek SKM ve KMT oranları ile nispi yem değerleri ise Kumgeçit köyüne ait ikinci tarladan elde edilmiştir (Tablo 4). 
Daha önce yapılan çalışmalarda yonca bitkisinde ADF oranlar1 \%18,7-34,9, NDF oranlar1 \%27,1-47,1, SKM oranlar1 \%63,6-74,4, KMT oranlar1 \%2,60-4,53 ve nispi yem değeri 126-262 arasında değiştiği bildirilmiştir (6,10,24-26). ADF ve NDF bitki hücre çeperini oluşturan bileşiklerdir. Yemlerde ADF ve NDF oranlarının mümkün olduğunca düşük olması istenir.
ADF oranının düşüklüğü sindirilebilir kuru madde oranının yüksek olmasını, NDF oranının düşüklüğü ise kuru madde tüketimi oranının yüksek olmasını sağlar. $\mathrm{Bu}$ iki faktör sayesinde belirlenen sindirilebilir kuru madde ve kuru madde tüketim oranları da nispi yem değerinin yüksek veya düşük olması üzerinde doğrudan etkili olmaktadır.

Tablo 4. Yonca genotiplerine ait ADF, NDF, SKM ve KTM oranları, nispi yem değerleri ve oluşan gruplar

\begin{tabular}{|c|c|c|c|c|c|c|}
\hline & Köy Adı & $\operatorname{ADF}(\%)$ & NDF (\%) & SKM (\%) & KMT (\%) & NYD \\
\hline 1 & Büyüktekören-1 & $27,7 \mathrm{bcd}$ & $37,0 \mathrm{c}-\mathrm{f}$ & $67,3 \mathrm{abc}$ & 3,25 a-e & 170 a-e \\
\hline 2 & Büyüktekören-2 & $27,5 \mathrm{bcd}$ & $36,1 \mathrm{c}-\mathrm{f}$ & $67,5 \mathrm{abc}$ & $3,32 \mathrm{a}-\mathrm{d}$ & $174 \mathrm{a}-\mathrm{d}$ \\
\hline 3 & Cayağzı & 30,9 a-d & $41,7 \mathrm{a}-\mathrm{f}$ & $64,8 \mathrm{ab}$ & $2,88 \mathrm{~b}-\mathrm{e}$ & $145 \mathrm{~b}-\mathrm{e}$ \\
\hline 4 & Celtiksuyu-1 & $28,0 \mathrm{bcd}$ & 37,4 b-f & $67,1 \mathrm{abc}$ & 3,22 a-e & 168 a-e \\
\hline 5 & Celtiksuyu-2 & $27,8 \mathrm{bcd}$ & $36,9 \mathrm{c}-\mathrm{f}$ & $67,2 \mathrm{abc}$ & 3,25 a-e & 169 a-e \\
\hline 6 & Celtiksuyu-3 & $27,1 \mathrm{bcd}$ & $36,0 \mathrm{c}-\mathrm{f}$ & $67,8 \mathrm{ab}$ & $3,34 \mathrm{abc}$ & $175 \mathrm{a}-\mathrm{d}$ \\
\hline 7 & Celtiksuyu-4 & $28,3 \mathrm{bcd}$ & 39,6 a-f & $66,9 \mathrm{abc}$ & 3,04 a-e & 157 a-e \\
\hline 8 & Celtiksuyu-5 & $28,3 \mathrm{bcd}$ & $37,5 \mathrm{~b}-\mathrm{f}$ & $66,8 \mathrm{abc}$ & 3,20 a-e & 166 a-e \\
\hline 9 & Celtiksuyu-6 & $30,3 \mathrm{a}-\mathrm{d}$ & 39,2 a-f & $65,3 \mathrm{a}-\mathrm{d}$ & 3,07 a-e & 156 a-e \\
\hline 10 & Dik-1 & 29,8 a-d & 38,9 a-f & $65,7 \mathrm{a}-\mathrm{d}$ & 3,09 a-e & 158 a-e \\
\hline 11 & Dik-2 & $28,4 \mathrm{bcd}$ & $37,5 \mathrm{~b}-\mathrm{f}$ & $66,8 \mathrm{abc}$ & 3,21 a-e & 167 a-e \\
\hline 12 & Dik-3 & $27,1 \mathrm{bcd}$ & $35,8 \mathrm{def}$ & $67,8 \mathrm{abc}$ & $3,35 \mathrm{abc}$ & $176 \mathrm{abc}$ \\
\hline 13 & Ekinyolu & 29,1 a-d & 38,7 a-f & 66,2 a-d & 3,10 a-e & 159 a-e \\
\hline 14 & Garip-1 & $32,2 \mathrm{a}-\mathrm{d}$ & 43,4 a-d & 63,8 a-d & $2,78 \mathrm{cde}$ & $138 \mathrm{cde}$ \\
\hline 15 & Garip-2 & 32,2 a-d & 40,5 a-f & 65,3 a-d & 2,99 a-e & 152 a-e \\
\hline 16 & Garip-3 & $32,6 \mathrm{abc}$ & 42,7 a-e & $63,5 \mathrm{bcd}$ & $2,82 \mathrm{cde}$ & $139 \mathrm{~b}-\mathrm{e}$ \\
\hline 17 & Garip-4 & $32,3 \mathrm{a}-\mathrm{d}$ & 41,6 a-f & $63,7 \mathrm{a}-\mathrm{d}$ & $2,90 \mathrm{~b}-\mathrm{e}$ & $144 \mathrm{~b}-\mathrm{e}$ \\
\hline 18 & Garip-5 & $31,3 \mathrm{a}-\mathrm{d}$ & $41,1 \mathrm{a}-\mathrm{f}$ & $64,5 \mathrm{a}-\mathrm{b}$ & 2,93 a-e & 147 a-e \\
\hline 19 & Güveçli-1 & 29,0 a-d & 38,7 a-f & $66,3 \mathrm{a}-\mathrm{d}$ & 3,10 a-e & 159 a-e \\
\hline 20 & Güveçli-2 & $28,6 \mathrm{bcd}$ & $38,1 \mathrm{a}-\mathrm{f}$ & $66,6 \mathrm{abc}$ & 3,16 a-e & 163 a-e \\
\hline 21 & Kumgeçit-1 & 28,9 a-d & 39,9 a-f & 66,4 a-d & 3,01 a-e & 155 a-e \\
\hline 22 & Kumgeçit-2 & $25,7 \mathrm{~d}$ & $33,9 \mathrm{f}$ & 68,9 a & $3,57 \mathrm{a}$ & $191 \mathrm{a}$ \\
\hline 23 & Kültür-1 & 29,4 a-d & 38,6 a-f & 66,0 a-d & 3,12 a-e & $160 \mathrm{ab}$ \\
\hline 24 & Kültür-2 & 29,0 a-d & $39,1 \mathrm{a}-\mathrm{f}$ & $66,3 \mathrm{a}-\mathrm{d}$ & 3,08 a-e & 159 a-e \\
\hline 25 & Kültür-3 & 29,9 a-d & $39,1 \mathrm{a}-\mathrm{f}$ & $65,6 \mathrm{a}-\mathrm{d}$ & 3,10 a-e & 158 a-e \\
\hline 26 & Kültür-4 & $27,1 \mathrm{bcd}$ & 34,5 ef & $67,8 \mathrm{abc}$ & $3,49 \mathrm{ab}$ & $184 \mathrm{ab}$ \\
\hline 27 & Kültür-5 & 28,1 a-d & $36,4 \mathrm{c}-\mathrm{f}$ & 67,0 abc & $3,33 \mathrm{abc}$ & 173 a-d \\
\hline 28 & Kültür-6 & 29,9 a-d & 39,5 a-f & 65,6 a-d & 3,07 a-e & 157 a-e \\
\hline 29 & Kültür-7 & 32,5 a-d & 42,8 a-e & 63,6 a-d & $2,81 \mathrm{cde}$ & 139 b-e \\
\hline 30 & Ormanard 1 & $35,7 \mathrm{a}$ & $46,4 \mathrm{a}$ & $61,1 \mathrm{~d}$ & $2,59 \mathrm{e}$ & $123 \mathrm{e}$ \\
\hline 31 & Sarıçiçek-1 & $30,5 \mathrm{a}-\mathrm{d}$ & 40,0 a-f & $65,1 \mathrm{a}-\mathrm{d}$ & 3,00 a-e & 152 a-e \\
\hline 32 & Sarıçiçek-2 & 29,7 a-d & 38,6 a-f & $65,8 \mathrm{a}-\mathrm{d}$ & 3,11 a-e & 159 a-e \\
\hline 33 & Sarıçiçek-3 & 29,8 a-d & 39,9 a-f & $65,7 \mathrm{a}-\mathrm{d}$ & 3,01 a-e & 154 a-e \\
\hline 34 & Sarıçiçek-4 & $32,7 \mathrm{abc}$ & $44,2 \mathrm{abc}$ & $63,5 \mathrm{bcd}$ & $2,72 \mathrm{cde}$ & $134 \mathrm{cde}$ \\
\hline 35 & Sarıçiçek-5 & $33,9 \mathrm{ab}$ & $45,7 \mathrm{ab}$ & $62,5 \mathrm{~cd}$ & $2,64 \mathrm{de}$ & $128 \mathrm{de}$ \\
\hline 36 & Yeniköy-1 & 29,0 a-d & 38,5 a-f & 66,3 a-d & 3,12 a-e & 160 a-e \\
\hline 37 & Yeniköy-2 & 28,9 a-d & $37,9 \mathrm{~b}-\mathrm{f}$ & 66,8 a-d & 3,17 a-e & 163 a-e \\
\hline 38 & Yeniköy-3 & $27,8 \mathrm{bcd}$ & $37,3 \mathrm{~b}-\mathrm{f}$ & $67,2 \mathrm{abc}$ & 3,22 a-e & 168 a-e \\
\hline 39 & Yeniköy-4 & $28,1 \mathrm{bcd}$ & $37,5 \mathrm{~b}-\mathrm{f}$ & $67,0 \mathrm{abc}$ & 3,21 a-e & 167 a-e \\
\hline \multicolumn{2}{|r|}{ Ortalama } & 29,6 & 39,2 & 65,9 & 3,09 & 158 \\
\hline & $\mathrm{P} \leq 0,01, \quad \mathrm{CV}(\%)$ & 10,61 & 8,72 & 2,20 & 8,81 & 10,91 \\
\hline
\end{tabular}

\section{SONUÇ}

Elde edilen bu sonuçlar doğrultusunda en yüksek yeşil ot ve kuru ot verimlerinin Garip köyüne ait birinci tarladan, en düşük ADF ve NDF oranları ile en yüksek sindirilebilir kuru madde, kuru madde tüketimi ve nispi yem değerlerinin de Kumgeçit köynüne ait ikinci tarladan elde edildiği belirlenmiştir. Yonca yetiştiriciliği yapacak üreticilere sertifikalı tohumluk kullanmaları tavsiye edilmektedir. Ancak herhangi bir nedenden dolayı sertifikalı tohumluk yerine yerel genotiplere ait tohumluk tercih edilmesi durumunda Garip köyü ve Kumgeçit köyünde yetiştiriciliği yapılan yoncalara ait tohumlukların tercih edilmesinin üretici için daha avantajlı olacağı anlaşılmıştır.

\section{Teşekkür}

$\mathrm{Bu}$ çalışma, İhsan ARSLAN'ın yüksek lisans tezinin özeti olup, Bingöl Üniversitesi Bilimsel Araştırma Projeleri Koordinasyon Birimi tarafindan desteklenmiştir (Proje No: BAP-GMYO.2019.00.001). 


\section{KAYNAKLAR}

[1] Soya H, Avcioğlu R, Geren H. Yem Bitkileri. Hasad Yayıncılık, İstanbul.; 2004.

[2] Avcioğlu R, Geren H, Tamkoç A, Karadağ Y. Yonca (Medicago sp. L.). In: Avcioğlu R, Hatipoğlu R, Karadağ Y, editors. Yem Bitkileri Baklagil Yem Bitkileri Cilt II. Tarım ve Köyişleri Bakanlığı, Tarımsal Üretim ve Geliştirme Genel Müdürlüğü, İzmir.; 2009.

[3] Ünal S. Yem Bitkileri. Tarım ve Köyişleri Bakanlığ1 Teşkilatlanma ve Destekleme Genel Müdürlüğü Televizyon Yoluyla Yaygın Çiftçi Eğitimi Projesi (YAYÇEP) Yayın No: 55, Ankara.; 2010.

[4] Ekiz H, Altınok S, Sancak C, Sevimay CS, Kendir H. Tarla Bitkileri (V. Yem Bitkileri Çayır ve Mera). Ankara Üniversitsi Ziraat Fakültesi Yayınları, Yayın No: 1588, Ankara.; 2011.

[5] Turan N, Celen AE, Ozyazici MA. Yield and Quality Characteristics of Some Alfalfa (Medicago sativa L.) Varieties Grown in the Eastern Turkey. 2017;22(2):160-5.

[6] Cacan E, Kokten K, Kaplan M. Determination of yield and quality characteristics of some alfalfa (Medicago sativa L.) cultivars in the east Anatolia region of Turkey and correlation analysis between these properties. Appl Ecol Environ Res. 2018;16(2):1185-98.

[7] Engin B, Mut H. Farklı Yonca Çeşitlerinin Ot Verimi ve Bazı Kalite Özelliklerinin Belirlenmesi. Yüzüncü Yıl Üniversitesi Tarım Bilim Derg. 2017;27(2):212-9.

[8] Demiroğlu G, Geren H, Avcioğlu R. Farklı Yonca (Medicago sativa L.) Genotiplerinin Ege Bölgesi Koşullarına Adaptasyonu. Ege Üniversitesi Ziraat Fakültesi Derg. 2008;45(1):1-10.

[9] Kavut YT, Çelen AE, Demiroğlu Topçu G, Kır B. Bazı Yonca (Medicago sativa L.) Genotiplerinin Farklı Lokasyonlardaki Verim ve Verim Özellikleri Üzerinde Bir Araştırma. 2Ege Üniversitesi Ziraat Fakültesi Derg. 2014;51(1):23-9.

[10] Çınar S. Çukurova Taban Koşullarında Bazı Çok Yillık Sicak Mevsim Buğdaygil Yem Bitkilerinin Yonca (Medicago sativa L.) ile Uygun Karışımlarının Belirlenmesi. Çukurova Üniversitesi Fen Bilimleri Enstitüsü Tarla Bitkileri Anabilim Dalı, Doktora Tezi, Adana.; 2012.

[11] MGM. Tarım ve Orman Bakanlığı Meteoroloji Genel Müdürlüğü, http://www.mgm.gov.tr. 2020.

[12] Demir Y. Bingöl Ovası'nda farklı fizyolojik üniteler üzerinde oluşmuş toprakların sınıflandırılması ve hidrolik özelliklerinin belirlenmesi. Atatürk Üniversitesi Toprak Bilimi ve Bitki Besleme Anabilim Dalı, Doktora Tezi, Erzurum.; 2016.

[13] Anonim. Tarimsal Değerleri Ölçme Denemeleri Teknik Talimatı, Yonca Türleri (Medicago L. species). Tarım ve Köyişleri Bakanlığı, Tohumluk Tescil ve Sertifikasyon Merkezi Müdürlüğü, Ankara.; 2001.

[14] Seydoşoğlu S, Avcıŏlu R. Çalımsı Yonca (Medicago arborea L.)' nın Hasat Dönemi ile
Biçim Oranının Verim ve Verime İlişkin Özelliklerine Etkisi Üzerinde Araştırmalar. Türk Tarım ve Doğa Bilim Derg. 2014;1(1):10-6.

[15] Kökten K, Kaplan M, Seydoşoğlu S, Tutar H, Özdemir S. Bingöl Koşullarında Bazı Burçak (Vicia ervilia (L.) Willd) Genotiplerinin Tohum Verimi ve Kalite Özelliklerinin Belirlenmesi. Ege Üniversitesi Ziraat Fakültesi Derg. 2019;56(1):2733.

[16] Morrison JA. Hay and pasture management. Chapter 6. In: Illinois Agronomy Handbook, 72.; 2003.

[17] Rohweder DA, Barnes RF, Jorgenses N. Proposed hay grading standards based on laboratory analyses for evaluating quality. J Anim Sci. 1978;47(3):74759.

[18] JMP 5.0.1. A Business Unit of SAS. USA:SAS Instute; 2002.

[19] Yeşil M, Şengül S. Türkiye'nin Değişik Yörelerinden Toplanan Yonca Ekotiplerinin Bazı Morfolojik Özelliklerinin Belirlenmesi Üzerine Bir Araştırma. Alınteri Zirai Bilim Derg. 2009;16(1):16.

[20] Artan H, Polat T. Şanlıurfa Sulu Koşullarında Bazı Çok Yıllık Sıcak Mevsim Buğdaygil Yem Bitkisi Türleriyle Yoncanın Saf ve Karışık Ekimlerinde Yem Kalite Değerlerinin Belirlenmesi. Harran Üniversitesi Vet Fakültesi Derg. 2019;8(1):85-92.

[21] Kır B. Kimi yonca çeştilerinde tohum ve ot verimi ile kalite özellikleri üzerinde bir araştırma. Ege Üniversitesi Fen Bilimleri Enstitüsü Tarla Bitkileri Anabilim Dalı, Doktora Tezi, İzmir.; 2006.

[22] Basbag M, Demirel R, Avci M. Determination of Some Agronomical and Quality Properties of Wild Alfalfa (Medicago sativa L.) Clones in Turkey. J Food, Agric Environ. 2009;7(2):357-9.

[23] Gökalp S, Yazıcı L, Çankaya N, İspirli K. Bazı Yonca (Medicago sativa L.) Çeşitlerinin TokatKazova Ekolojik Koşullarında Ot Verimi ve Kalite Performanslarının Belirlenmesi. Gaziosmanpaşa Üniversitesi Ziraat Fakültesi Derg. 2017;34(3):114-27.

[24] Açıkbaş S, Albayrak S, Türk M. Doğal Vejetasyondan Toplanan Bazı Yonca (Medicago sativa L.) Genotiplerinin Ot Verim Ve Kalitelerinin Belirlenmesi. Türkiye Tarımsal Araştırmalar Derg. 2017;4(2):155-62.

[25] Tan M, Severoğlu S, Yazıcı A. Çayır ve Meralarda Yetişen Bazı Baklagil ve Buğdaygil Yem Bitkilerinin Besleme Değerlerinin Belirlenmesi. Iğdır Üniversitesi Fen Bilim Enstitüsü Derg. 2019;9(3):1776-84.

[26] Çaçan E, Aydın A, Başbağ M. Bingöl Üniversitesi Yerleşkesinde Yer Alan Bazı Baklagil Yem Bitkilerine Ait Kalite Özelliklerinin Belirlenmesi. Türk Tarım ve Doğa Bilim Derg. 2015;2(1):10511. 